\author{
Kalas Vivien \\ ELTE ÁJK Politikatudományi Intézet \\ Témavezető: Navracsis Tibor egyetemi docens
}

DOI: 10.55052/themis.2021.2.153-172

\title{
Az európai integráció jövőjéről folytatott viták meghatározó tényezői: A kormányközi konferenciák, az Európai Konvent és az Európa jövőjéről szóló konferencia összehasonlító elemzése
}

\section{Bevezetés}

Az Európai Unióval (EU) kapcsolatos stratégiai kérdésekről, a szükséges új irányvonalakról hagyományosan az úgynevezett rendszerfeletti szinten születnek a döntések. Kulcsszereplői a tagállamok és egyik fö terét a kormányközi konferenciák jelentik, ahol a nemzetek vezetői a közösség alapját képező szerződések módosításairól határoznak. ${ }^{1}$ A gyakorlatban azonban, az európai integráció több mint hetven éves történetét ${ }^{2}$ tekintve, a tagországok kormányainak képviselői - esetenként más szereplőkkel kiegészülve - e mellett más keretek között is folytattak megbeszéléseket arról, milyen (új) elvek mentén képzelik el hosszú távon együttműködésüket.

A 2021. május 9-én hivatalosan kezdetét vevő Európa jövőjéről szóló konferencia (COFoE) a tizenharmadik alkalom, mikor a végrehajtó hatalmak tagjai a közösség müködéséről, annak reformjáról egyeztetnek. Valamennyi esetben tárgyalássorozatról beszélhetünk, hiszen az egyeztetések több hónapon át, több szinten zajlottak. Általános célkitűzésüket figyelembe véve a tagállamok mindannyiszor a közösség általános, alapvető irányvonalait akarták - és akarják - (újra)definiálni, akár intézményi, akár szakpolitikai vonatkozásban, az elérni kívánt

\footnotetext{
${ }^{1}$ Peterson - Bomberg 1999.

2 Tanulmányomban az európai integráció kezdetét az 1950-1951-es kormányközi konferenciától eredeztetem, mely a Párizsi Szerződés aláírásával zárult, létrehozva ezzel az Európai Szén- és Acélközösséget (ESZAK).
} 
végeredmény szempontjából viszont a megbeszélések színterei három nagyobb kategóriába sorolhatóak.

Az elsőbe a kormányközi konferenciák (Intergovernmental Conferences - IGCs) tartoznak, melyek mindegyike azt a célt szolgálta, hogy a kormányok képviselői megegyezésre jussanak egy új szerződés, vagy a már meglévő szükséges változtatásainak tartalmi kérdéseiben, a folyamat pedig a megszületett jogi dokumentum aláírásával zárult. Az 1950 óta eltelt időszakban ilyen konferenciából összesen tizenkettőt rendeztek tizenegy alkalommal, közéjük sorolva nem csupán a módosítások jóváhagyásával, de az alapszerződések elfogadásával végződőket is. Ezek eredményeképpen jött létre az Európai Szén- és Acélközösséget megteremtő Párizsi Szerződés (1950-1951), az Európai Gazdasági Közösséget (EGK), illetve az Európai Atomenergia Közösséget (EURATOM) létrehozó szerződés (mindkettő az 1956-1957-es kormányközi konferencia folyománya), az Egyesítési Szerződés (1965), a Luxembourgi és Brüsszeli (Első és Második Költségvetési) Szerződés (1969-1970 és 1975), továbbá az Egységes Európai Okmány (1985-1986). Hasonló tárgyalások előzték meg az Európai Unióról szóló szerződést (1990-1991, két kormányközi konferencia a gazdasági és monetáris unióról, valamint a politikai unióról), az Amszterdami (1996-1997) és a Nizzai Szerződést (2000), az Európai Alkotmányt létrehozó szerződést (2003-2004), illetve a Lisszaboni Szerződést (2007) is.

A második típust a 2002-2003-as Európai - vagy Alkotmányozónak is nevezett - Konvent (EK) jelenti. A résztvevők ekkor egy kormányközi konferenciára dolgoztak ki javaslatot arra vonatkozóan, miképpen lehetne megújítani az Európai Uniót. Noha végül egy, mindenki által elfogadott dokumentumot tettek le az asztalra, megvolt az a lehetőségük is, hogy több, akár egymásnak ellentmondó nézeteket tartalmazó anyagot adjanak át a tagállamok vezetőinek. A konventtagok tehát annak tudatában végezték munkájukat, hogy meglátásaikat később, a jogszabályok szerinti szerződésmódosítási eljárás során még egyszer újratárgyalják majd a végrehajtó hatalmak képviselői.

A 2021-2022-es Európa jövőjéről szóló konferencia mindkét előző kategóriától különbözik. Noha a rendezvény egyik fő rendeltetése, hogy új irányokat szabjon az EU-nak, ennek ellenére nem tartozik az Európai Unióról szóló szerződés 48. cikkelyének hatálya alá, vagyis nem egy kormányközi konferenciát előkészítő konvent ${ }^{3}$ és nem is zárul majd egy új, az Európai Unió működésének alapjait meghatározó szerződés aláírásával. Célja mindössze az, hogy a politikusok a polgárokkal közösen

\footnotetext{
${ }^{3}$ Council of the European Union 2021.
} 
alakítsanak ki egy képet az Unió jövőjéről, azt követően minden intézmény a saját hatáskörével összhangban tesz eleget a konferencián megfogalmazottaknak .

Kutatásomban ezeket a színtereket hasonlítom össze, arra a két kérdésre keresve a választ, milyen tényezők jellemezték a döntéshozatali folyamatokat a három esetben, illetve felfedezhetőek-e különbségek az egyes típusok között az eltérő célok tükrében?

A szöveg négy egységre tagolódik. Az első három fejezetben áttekintem a különböző csoportok résztvevőinek körét, a tárgyalássorozatok felépítését, illetve feltárom, hogy a legfelső szinteken melyek voltak a viták során a meghatározó törésvonalak, mik befolyásolták a szereplők magatartását. Az utolsó részben a következtetéseim révén kísérelek meg választ adni kutatási kérdéseimre. A tanulmány lezárása - 2021. október 31. - mintegy hat hónappal az Európa jövőjéről szóló konferencia vége előtt történt, az addig lezajlott rendezvények azonban lehetővé teszik a folyamat - valamennyi szempont mentén történő - összehasonlítását a Konventtel, valamint a kormányközi konferenciákkal.

Írásomban a „tagállam” kifejezéssel az egyes nemzetek kormányaira, illetve azok képviselőire utalok, a végrehajtó hatalmak preferenciáira és a tárgyalások kimenetelére közvetlenül, vagy közvetetten befolyást gyakorló egyéb belpolitikai szereplőket - parlamenti pártok, érdekcsoportok fogalomhasználatban megkülönböztetem a tagországoktól.

\section{Kormányközi konferenciák}

Az Európai Unióban új szerződés kidolgozására, vagy a már meglévők módosítására 2009-ig kizárólag kormányközi konferenciák keretében volt lehetőség. A Lisszaboni Szerződésben bevezetésre került az egyszerüsített felülvizsgálati eljárás intézménye is, mely során azonban csak korlátozott változtatásokat lehet végrehajtani, ${ }^{5}$ így az európai országok együttmüködését alapjaiban meghatározó reformokról továbbra is az IGCken születik döntés.

A szerződésmódosítás folyamatának szabályait már a Párizsi Szerződés is tartalmazta, az azóta eltelt időszakban pedig a tagállamok csupán kisebb módosításokat hajtottak végre rajta. Felülvizsgálatot valamely

\footnotetext{
${ }^{4}$ Joint Declaration 2021.

5 Erről bővebben: Lisszaboni Szerződés az Európai Unióról szóló szerződés és az Európai Közösséget létrehozó szerződés módosításáról. Az Európai Unió Hivatalos Lapja, C 306/1; 2007.12.17., 48. cikkely 6. bekezdés.
} 
tagország kormánya, az Európai Bizottság (EB) (1957-ig: Főhatóság) és 2009-től az Európai Parlament (EP) is kezdeményezhet. A végrehajtó hatalmak képviselőiből álló konferencia összehívásáról a Tanács - később pedig az Európai Tanács (EiT) - dönt, a valamennyi tagállam által aláirt szerződést pedig a hazai jogszabályoknak megfelelően ratifikálniuk kell a nemzeteknek, és csak azt követően léphet hatályba.

\subsection{Résztvevők és felépítés}

A kormányközi konferenciák szerződésben meghatározott egyedüli résztvevői a tagállamok, ám a gyakorlatban ma már ennél több szereplő van jelen a tárgyalásokon. A Bizottság képviselőjének kormányközi konferenciákon való részvételi joga az 1985-1986-os IGC-n lett garantálva, ${ }^{6}$ de ugyanígy szerephez jut a Főtitkárság is többek között a szerződéstervezetek megírása, illetve jogi tanácsadás kapcsán, továbbá az EP fokozatos erősödése nyomán, 1996-tól kezdődően képviselői szintén bekapcsolódhatnak a folyamatba. ${ }^{7}$ Szavazati joggal azonban nem rendelkeznek ezek az intézmények. A 2003-2004-es, Európai Alkotmányt megvitató IGC-n pedig a 2004-ben csatlakozó tíz kelet-közép-európai ország, Románia, Bulgária és Törökország is jelen lehetett. ${ }^{8}$

Az egyeztetések több szinten - hivatalnoki, politikusi - zajlanak, és 1985-től három fórumot különböztethetünk meg. ${ }^{9}$ Leggyakrabban a köztisztviselők találkoznak, ahol az IGC-k kettős - jogi és politikai természetéből fakadóan, elsősorban a technikai jellegű kérdéseket vitatják meg. Az Európai Parlament két legnagyobb frakciójának egy-egy delegáltja is itt vehet részt megfigyelőként. Az érzékeny politikai témákról a legfelső szinten - az Európai Tanács ülésein - döntenek az állam- és kormányfök, ám ezek gyakran mindössze öt százalékát teszik ki a megtárgyalandó ügyeknek. ${ }^{10}$ A köztes fórumot a külügyminiszterek megbeszélései jelentik, amelyek kezdetén az EP elnöke szintén részt vehet, ám az érdemi tárgyalások megkezdése előtt távoznia kell. ${ }^{11}$

\footnotetext{
${ }^{6}$ Christiansen 2002. 39.

${ }^{7}$ Slapin 2011.

${ }^{8}$ Beach 2012.

${ }^{9}$ Laursen 2012. 6.

${ }^{10}$ Stubb 2002. 21.

${ }^{11}$ Christiansen 2002. 43.
} 


\subsection{A döntéshozatali folyamat jellemzői}

Ahogyan azt az előző alfejezetben kifejtettem, jogilag ugyan egyedül a tagállamok a szereplői a kormányközi konferenciáknak, mellettük mégis több más szereplő is bekapcsolódik a folyamatokba. A Főtitkárság és idővel az Európai Bizottság, valamint az Európai Parlament képviselői helyet is kaptak a tárgyalásokon, de az európai pártcsaládok ugyancsak igyekeznek érdekeiknek megfelelően formálni azok menetét. ${ }^{12} \mathrm{~A}$ szupranacionális intézményeknek elsősorban napirend meghatározó szerepe jelentékeny, ahogyan az az $1985-1986-o s$ IGC- $n,{ }^{13}$ vagy éppen az Amszterdami Szerződést megelőző kormányközi konferencián is megmutatkozott. ${ }^{14}$ Tekintettel azonban arra, hogy a szerződések aláírása kizárólag a tagállamok joga, céljaikat csak akkor tudták érvényre juttatni, ha azokat legalább néhány nemzet is támogatta.

Noha egy új szerződés elfogadása előtt az országok között természetszerüleg jelen van az a kérdés, hogy szorosabbra füzzék-e együttmüködésüket és, ha igen, milyen mértékben, amikor viszont a kormányközi konferenciákon intézményi reformokról vagy szakpolitikai kérdésekről tárgyaltak a meghatározó törésvonalat mégsem ez, hanem a - gazdaságilag, vagy demográfiai szempontból - nagy, illetve kis államok - és eltérő érdekeik - közötti véleménykülönbség jelentette. Ez megmutatkozott egyebek mellett a Bizottság átalakításáról és a Tanács döntéshozatali eljárásának módosításáról való egyeztetéseken, ${ }^{15}$ továbbá az egységes piac létrehozásáról szóló megbeszéléseken is. ${ }^{16}$

Az egyes kormányközi konferenciákat és azok döntéshozatali folyamatát legjobban és legpontosabban egyedi történelmi, politikai kontextusukat figyelembe véve lehet értelmezni és értékelni. A párhuzamosan zajló nemzetközi és belpolitikai események ugyanis befolyással bírnak a megvitatandó témák körére, a szükségesnek tartott - intézményi vagy szakpolitikai - reformjavaslatokra, ${ }^{17}$ vagy éppen a tagállamok egyes ügyekben elfoglalt álláspontjára. A Maastrichti Szerződéshez vezető tárgyalásokkal egyidőben zajlott Németország újraegyesítése, illetve az öbölháború, melyek a külpolitikai kooperáció kérdését helyezték előtérbe, ${ }^{18}$ az 1985-1986-os IGC-n pedig a felek Spanyolország és

\footnotetext{
12 Falkner 2002.

${ }^{13}$ Bickerton et al. 2015

${ }^{14}$ Devuyst 1998; Hix 2002.

${ }^{15}$ Slapin 2011.

${ }^{16}$ Moravcsik 1991.

${ }^{17}$ Sverdrup 2002.

${ }^{18}$ Moravcsik - Nicolaidis 1998
} 
Portugália jövőbeli csatlakozására készülve folytattak megbeszéléseket. ${ }^{19}$ Az időközben bekövetkező kormányváltások szintén éreztették hatásukat. Ez okból módosult az Egyesült Királyság és Franciaország hozzáállása az Európai Parlament szerepéhez az 1996-1997-es kormányközi konferencián ${ }^{20}$ és ugyancsak emiatt fogadta el végül Spanyolország a szavazási súlyok megváltoztatását a Tanácsban a 2003-2004-es IGC-n. ${ }^{21}$

Az egyedi jellemzőkön túl két tényező, az egyhangúság (unanimity) és a sikeres ratifikáció követelménye gyakorolt leginkább befolyást a tárgyalások alakulására. Egy új szerződést kizárólag akkor írhatnak alá az európai vezetők, ha annak tartalmával valamennyi nemzet egyetértett. Az IGC-ken tehát az államok élhetnek a vétózás lehetőségével, amellyel egyfelől megakadályozhatják az integráció túlzott elmélyítését, másfelől jobb alkupozícióba is kerülhetnek általa. Mindennek ellenére a politikusok a legtöbb kérdésben igyekeznek megegyezésre jutni, fontosabb ugyanis, hogy valamiben megállapodjanak, mint az, hogy nemzeti érdekeiket megvédve, de teljesen eredménytelenül álljanak fel a tárgyalóasztal mellöl. ${ }^{22} \mathrm{Az}$ egyezség kialakulását nagyban segíti, hogy az országok másmás megítéléssel vannak egy-egy ügy iránt, a kevésbé érzékeny területeken készek kompromisszumot kötni, a számukra fontos témákban viszont tárgyalópartnereiktől várják el ugyanezt. ${ }^{23}$

A végeredmény belpolitikai szereplők - pártok, választópolgárok - általi megerősítésének fontossága szintén irányt szab az egyeztetéseknek. Az elfogadott dokumentum ugyanis akkor lép hatályba az aláírást követően, ha annak a hazai jóváhagyása - parlament által, népszavazás útján - is megtörténik a tagállamokban, azok alkotmányos előirásainak megfelelően, ám minél távolabb esik egymástól az otthon elfogadható és a nemzetközi téren elért megállapodások köre, annál nagyobb valószínüséggel lesz sikertelen a ratifikáció, ahogyan az történt például az Európai Alkotmányt létrehozó szerződés esetében. A vitákon pedig az az európai vezető kerülhet előnyösebb helyzetbe, akit hazájában szigorúbb korlátok kötnek. ${ }^{24}$

\footnotetext{
${ }^{19}$ Budden 2002.

${ }^{20}$ Moravcsik - Nicolaidis 1999. 68.

${ }^{21}$ Beach 2012. 232.

22 Stubb 2002.

${ }^{23}$ Hix 1999.

${ }^{24}$ Putnam 1988.
} 


\section{Szakítás a korábbi gyakorlattal: az Alkotmányozó Konvent}

A Nizzai Szerződés aláirása és ratifikálása ellenére számos kérdésben mint például az intézményi működés átalakítása a közelgő keleti bővítésre való tekintettel, vagy a demokratikus legitimáció erősítése - a tagállamoknak nem sikerült egyezségre jutniuk, így azok továbbra is nyitva maradtak. Ennek ténye egyfelől egy újabb szerződésmódosítási folyamatot vetített előre, másfelől a politikusok részéről felmerült az az igény is, hogy változtassanak addigi gyakorlatukon és új módszerek segítségével döntsenek a szükséges változtatásokról. ${ }^{25} \mathrm{Az}$ európai vezetők ez irányú szándékukat rögzítették is a Nizzai Szerződéshez csatolt 23. számú nyilatkozatban.

Mindezekre reflektálva az Európai Tanács 2001. decemberi, Laekenben rendezett csúcstalálkozóján az uniós állam- és kormányfők egy konvent összehívása mellett döntöttek, hogy annak keretén belül, minél szélesebb körben és minél nagyobb nyilvánosság előtt vitassák meg az Unió jövőjét érintő legfontosabb ügyeket és dolgozzanak ki rájuk lehetséges cselekvési irányokat, melyek alapját képezik majd az utána jövő kormányközi konferencia keretében folyó tárgyalásoknak. Következésképpen a Konvent fő feladata a következő IGC előkészítése volt. A politikusok négy nagyobb kérdéskört jelöltek meg olyan témaként, amelyekkel elsődlegesen foglalkoznia kell majd az egyeztetéssorozatnak: a kompetenciák meghatározása és világos elhatárolása a közösségi és a tagállami szint között, intézményi reformok és a döntéshozatali eljárás hatékonyabbá tétele, a jogi aktusok egyszerűsítése, továbbá hosszú távon egy európai alkotmány létrehozása. ${ }^{26}$ Az EiT-től kapott mandátum értelmében, a konszenzus kialakulásától függően, a végső dokumentumnak nem kizárólag a különböző véleményeket kellett összefoglalnia, helyette tartalmazhatott konkrét ajánlásokat is a reformokra vonatkozóan.

\subsection{Résztvevők és felépítés}

Az Európai Konvent munkáját a 2002. február 28-án rendezett alakuló ülésével kezdte meg, az elkészült alkotmánytervezetet pedig 2003 júniusában fogadta el az Európai Tanács, thesszaloniki ülésén.

\footnotetext{
${ }^{25}$ de Schoutheete - Wallace 2002.

${ }^{26}$ European Council 2001.
} 
Az ígéreteknek megfelelően, a kormányközi konferenciákon megszokott résztvevőkhöz képest a Konvent összetétele sokkal heterogénebb volt. Az Európai Tanács elnöknek Valéry Giscard d'Estaing-t, korábbi francia államföt nevezte ki, a két alelnök pedig Giuliano Amato és Jean-Luc Dehaene egykori olasz, illetve belga miniszterelnök lett. Mellettük további százkét teljes jogú tagja volt a Konventnek: a tizenöt tagállam állam- és kormányfőjének egy-egy képviselője, valamint nemzeti parlamentjének két-két küldötte, tizenhat fő az Európai Parlamentből és két személy az Európai Bizottság képviseletében. Az előző fejezetben felsorolt tagjelölt országok ugyancsak jelen lehettek az egyeztetéseken egy kormányzat részéről és két parlamentből érkező politikussal, azzal a kitétellel, hogy nem jelenthetik gátját a konszenzus kialakulásának. Ezen túlmenően, megfigyelői státuszban szintén ott volt az európai ombudsman, az Európai Gazdasági és Szociális Bizottságból, illetve a szociális partnerektől háromhárom személy, a Régiók Bizottságából pedig hat ember. A valóságban azonban mintegy kétszer ennyien vettek részt a Konvent munkájában, a teljes jogú tagok ugyanis egy-egy helyettest is megnevezhettek, akik távollétükben képviselik őket a tanácskozáson, így ő nekik is biztosított volt a javaslattételi jog.

A Konvent munkájának pontos menetét az elnökség határozta meg. A testület az elnökön és az alelnökökön túl tíz tagból állt: két-két fö a nemzeti, illetve Európai Parlamentből, a Bizottság képviselői, valamint az Európai Unió Tanácsának soros elnökségét betöltő ország kormányának delegáltja. Ez az EK időszaka alatt spanyol, dán, görög, majd azt követően olasz politikust jelentett. Az elnökség tizenharmadik tagját egy szlovén politikus jelentette, aki a tagjelölt államokat képviselte a testületben. Az egyes dokumentumok - javaslatok, módosítások - pontos megszövegezéséért a Főtitkárság volt a felelős.

A felek a tanácskozások során különös figyelmet fordítottak az átláthatóság tényleges megvalósítására is, melyből fakadóan minden dokumentumot elérhetővé tettek a nyilvánosság számára, kivételt ez alól egyedül az elnökség ülései képeztek.

Az Európai Konvent keretében folyó viták három fórumon zajlottak. A plenáris üléseken valamennyi teljes jogú, illetve megfigyelői státusszal bíró tag jelen lehetett, havonta legalább egyszer találkoztak és hivatalosan itt születtek a végső döntések egy-egy kérdésben. A cél ekkor a konszenzus (consensus) elérése volt, mely több volt az abszolút többségnél, de kevesebb az egyhangú támogatásnál, sokkal inkább a „nagyarányú többséggel" történő elfogadást jelentette. ${ }^{27}$

\footnotetext{
${ }^{27}$ Magnette - Nicolaidis 2005. 97.
} 
Következésképpen egyik szereplőnek sem állt módjában megvétózni valamely változtatást és ily módon megakadályozni azt, amennyiben egy tag mégis megpróbált élni a tiltakozás e formájával, akaratát a többi résztvevő egyszerüen figyelmen kívül hagyta. ${ }^{28} \mathrm{Az}$ egyes plenáris üléseken tárgyalt napirendi pontok, javaslatok kidolgozásáért a Giscard d'Estaing vezette testület volt felelős. Az elnökség havonta két alkalommal ülésezett, rendszerint a plenáris vitákat megelőzően és azokat követően. A fennmaradó napokon a konventtagok kisebb munkacsoportokban szám szerint tizenegyben - folytattak megbeszéléseket a különböző szakpolitikákról, az azokban szükséges reformokról.

A több mint egy éven át tartó folyamat a munkamegosztást illetően három nagyobb szakaszra volt bontható. Az első 2002 őszéig tartott és az odafigyelés, az európai polgárok észrevételeinek összegyűjtése jellemezte. A 2002-es esztendő végéig tartó második szakasz középpontjában a tanácskozások álltak. Ekkor volt a legjelentősebb szerepük a munkacsoportokban zajló megbeszéléseknek, illetve a plenáris ülések vitáinak. Az utolsó időszak 2003 júniusában zárult, és ezekben a hónapokban történt az egységes tervezet megalkotásának legnagyobb része. ${ }^{29}$ Ahogyan fentebb kifejtettem, ez utóbbi ugyan nem tartozott szükségszerüen a Konvent feladatai közé, azonban Giscard d'Estaing már nyitóbeszédében egyértelművé tette, hogy egy darab, közös javaslat kidolgozására fognak törekedni, amely első lépés lesz az európai alkotmányos szerződéshez vezető úton. ${ }^{30}$

\subsection{A döntéshozatali folyamat jellemzői}

Noha a konventtagok többsége - több mint hetven százaléka - valamely parlament soraiból került ki, ide értve az EP képviselőit is, meghatározó jelentősége mégis a tagállamok akaratának volt az intézményközi vitákban. Mind a nemzeti törvényhozások, mind az Európai Parlament a saját szerepének megerősítésre törekedett, azonban ez nem, vagy csak korlátozottan sikerült. Az egyes országok parlamentjei a közösségi jogalkotás feletti ellenőrzés jogát szerették volna maguknak biztosítani, a végső tervezet értelmében viszont csak bizonyos esetekben kapták volna meg ezt a lehetőséget. ${ }^{31}$ Az EP pedig legfőképpen azokban az ügyekben tudott eredményt elérni, amelyek nem voltak kényesek a tagállamok

\footnotetext{
${ }^{28}$ Magnette - Nicolaidis 2005.

${ }^{29}$ Beach 2012.

${ }^{30}$ Giscard d'Estaing 2002.

${ }^{31}$ Dehousse - Deloche-Gaudez 2005.
} 
szempontjából. Ilyen volt például az alkotmány kifejezés megjelenése az elkészített dokumentum címében, ${ }^{32}$ ám a fogalom használatától maguk a tagországok sem zárkóztak el, már a laekeni következtetéseikben is utaltak rá. Ennél fontosabb volt számukra a jogalkotás módjának kérdése, így az Európai Parlamentnek nem sikerült érvényre juttatnia azon szándékát, hogy az együttdöntési eljárást valamennyi szakpolitikai területre kiterjesszék.

A Konventen nem csupán az államok és más intézmények, de a tagországok között is húzódtak ellentétek. A legfőbb nézeteltérések a két hagyományosnak nevezhető törésvonal mentén voltak megfigyelhetőek. Egyrészről az Európai Unió egységének szorosabbra füzése mellett érvelő, illetve ezzel szemben, inkább a kormányközi jelleget preferáló szemléletmódok találkoztak, másrészről a nagy és kis nemzetek közötti különbségek rajzolódtak ki, amikor az integráció jövőjét érintő szakpolitikai, vagy intézményi reformokról folyt a vita. A föderálisabb Uniót vágyó országok a többségi döntéshozatal szabálya alá eső területek bővítését szorgalmazták a Tanácsban, a másik oldal viszont az egyhangú szavazás megőrzésének fontosságát hangsúlyozta. Néhány nemzetnek köztük Németországnak és Olaszországnak - ennél nagyobb ambíciói is voltak, az Európai Bizottság - és így az EU közösségi dimenziójának megerősítése végett, az elnök megválasztásának jogát az Európai Parlament számára biztosították volna. ${ }^{33}$

A második törésvonal egyik leglátványosabban az Európai Tanáccsal kapcsolatban mutatkozott meg. A nagy tagállamok - Franciaország, Spanyolország és az Egyesült Királyság, Németország ebben az esetben kivételnek bizonyult - az EB helyett az EiT - és vele együtt a nemzetek szerepét kívánták jelentékenyebbé tenni egy állandó elnök személye formájában, ${ }^{34}$ aki idővel egyszersmind az Európai Unió első embereként tudja magát pozicionálni. A kis országok - például a Benelux államok ugyanakkor nem akartak változást, mivel attól tartottak, hogy az esetben sérülne az egyenlőség a tagállamok között és néhány, erősebb befolyással bíró nemzet akarata válna dominánssá. ${ }^{35}$ Habár ezen a területen végül az előbbi csoport elképzelése érvényesült, hiszen az alkotmánytervezetben egy állandó vezetőre tettek javaslatot, a Konvent döntéshozatali folyamatában összességében mégsem volt magától értetődő, hogy a nagy államok az eredményesebbek a tárgyalások során.

\footnotetext{
${ }^{32}$ Beach 2012.

${ }^{33}$ Magnette - Nicolaidis 2004.

${ }^{34}$ Az Európai Tanács elnöke ekkor - egészen 2009-ig - az EU Tanácsának soros elnökségét betöltő ország vezetője volt, akinek nem volt kiemelt szerepe a többi állam- és kormányföhöz képest.

${ }^{35}$ Magnette - Nicolaidis 2005.
} 
A megbeszélésekre - és esetenként a kimenetelükre is - érdemi befolyást sokkal inkább annak ténye gyakorolt, hogy az Európai Konvent a következő kormányközi konferenciát készítette elő. Noha a konszenzusra törekvés miatt nem volt szükség minden szereplő támogatására, ennek ellenére a jövőbeni IGC tudatában a végrehajtó hatalmak képviselői olyan ügyekben is engedményeket tettek, melyeket máskülönben nem támogattak volna akár egyet nem értésük okán, akár a hazai ratifikáció sikerességére való tekintettel, ugyanis tisztában voltak vele, hogy a kormányközi konferencián ismét előkerülnek azok a kérdések és ott megvétózhatják majd őket. ${ }^{36}$ Jól alátámasztja ezt, hogy bár a benyújtott szerződéstervezet különböző pontjait több ország - Spanyolország, Lengyelország, Portugália, Ausztria - kormánya is kritikával illette, ${ }^{37}$ végül ők is elfogadták azt.

\section{Vitasorozat szerződésmódosítás nélkül: az Európa jövőjéről szóló konferencia}

Az Európa jövőjéről szóló konferencia ötlete Emmanuel Macron francia államfőtől származik, aki már 2017-es elnökjelölti kampányában nagyratörő terveket fogalmazott meg a közösség jövőbeli irányvonalaival kapcsolatban. Ebbe illeszkedett bele a 2019. márciusi, európai polgárokhoz intézett felhívása, amiben az EU megújításának szükségessége mellett érvelt, melynek folyamatába a civilek bevonását is szorgalmazta, mindezt pedig egy Európáról szóló konferencia megrendezésével kívánta megvalósítani. ${ }^{38}$ A rendezvény később, Ursula von der Leyen bizottsági elnökké válását követően hivatalosan is európai uniós kezdeményezéssé vált. Az eredeti szándékok szerint 2020-tól kezdődően két esztendőn át tartott volna, a koronavírus-járvány kitörése miatt azonban a hivatalos megnyitója egy évvel később, 2021. május 9én, Európa napján volt, 2022-re előirányzott befejezése viszont változatlan maradt.

A kezdeményezők ez alkalommal nem határoztak meg olyan témákat, amikre az egyeztetések során különös hangsúlyt kell fektetni, a megbeszélések tárgyaként valamennyi szakpolitikai területet megjelölték. A konferencia mandátuma szerint nem irányul szerződésmódosításra, lezárulta után, az elnöksége számára átnyújtott jelentésben foglaltak

\footnotetext{
${ }^{36}$ König - Slapin 2006.

${ }^{37}$ Magnette - Nicolaidis 2004. 402-403.

${ }^{38}$ Macron 2019.
} 
véghezvitele érdekében, minden intézmény saját hatáskörével összhangban cselekedhet. ${ }^{39}$

\subsection{Résztvevők és felépítés}

A konferencia szerkezete alulról építkező, négy nagyobb szintjét lehet megkülönböztetni, azon személyek köre pedig, akik bekapcsolódhatnak a munkájába, rendkívül széles. Civilek és politikusok, helyi, nemzeti és uniós érdeket megjelenítők egyaránt részt vesznek a tanácskozásokon. A legalsó szintet a rendezvénysorozat hivatalos online platformján meghirdetett események, valamint a nemzeti, illetve regionális keretek között megrendezett civil vitafórumok jelentik. Az ezeken megfogalmazott ajánlások a két következő szinten kerülnek továbbgondolásra. Egyfelől azon a négy európai polgári panelen, melyeken 200-200 polgár vesz részt és ahol szeptembertől januárig három ülésszakon vitatnak meg egy-egy nagyobb témakört. ${ }^{40} \mathrm{~A}$ másik szintet a konferencia plenáris része jelenti, ahová az uniós vitafórumok javaslatait is becsatornázzák. A plenáris üléseken 449 fő van jelen: száznyolc politikus az Európai Parlamentből, ötvennégy delegált a tagállamok képviselőit tömörítő Tanácsból államonként kettő -, az Európai Bizottságot pedig három személy képviseli. Mellettük a nemzeti parlamentekből összesen száznyolc személy vesz részt - országonként négyen - és száznyolcan a civilek közül. Közéjük sorolandó nyolcvan fő az európai panelekből, huszonhét tag nemzetenként egy-egy - az országos szinten rendezett vitafórumokból, vagy bármely, a konferenciával összefüggő eseményről és az Európai Ifjúsági Fórum elnöke. Ezen túlmenően a szociális partnerek részéről jelen van tizenkét, illetve a civil szervezetek képviseletében nyolc ember, az Európai Gazdasági és Szociális Bizottságnak és a Régiók Bizottságának egyaránt tizennyolc, a helyi és regionális önkormányzatoknak pedig hathat delegáltja van. Nemzetközi téma esetén az Európai Unió külügyi és biztonságpolitikai főképviselője is részt vesz a tanácskozáson. Az október 22-23-ai plenáris ülésre meghívást kaptak a Nyugat-Balkán országai is.

A konferencia legfelső szintjét a hármas elnökség jelenti, mely az EB és az EP elnökeiből, továbbá az EU Tanácsának soros elnökségét ellátó állam vezetőjéből tevődik össze. Ezt a posztot a rendezvény ideje alatt a portugál, szlovén, majd a francia állam- illetve kormányfő tölti be. Munkájukhoz egy Igazgatóság és egy titkárság nyújt segítséget, melyek a

\footnotetext{
${ }^{39}$ Joint Declaration 2021.

${ }^{40}$ A résztvevőket a szervezők véletlenszerüen választották ki, ügyelve ugyanakkor egyebek mellett a földrajzi, nemi és életkori reprezentativitásra.
} 
konferencia lebonyolításáért felelősek. Ezeket a három uniós intézmény hét-hét képviselője alkotja.

\subsection{A döntéshozatali folyamat jellemzöi ${ }^{41}$}

Az Európa jövőjéről szóló konferencián részt vevő számos, más-más érdekeket képviselő intézmény - például civilek, tagállamok, uniós intézmények - ellenére az első hat hónap során nem lehetett egyértelmü különbséget tenni közöttük az Unió új irányvonalaival kapcsolatos elgondolásaik tekintetében. Úgy a civil szervezetek, mint a tagországok közül érveltek a transznacionális pártlisták bevezetése mellett a 2024-es európai parlamenti választásokra, és hasonlóképpen átfedés volt megfigyelhető a döntéshozatal reformjával összefüggő vélemények terén is az érdekképviseleti szervezetek és a nemzetek között. Mindemellett ugyanakkor az egységes, intézményi álláspontokat tekintve elmondható, hogy míg a Bizottság bármilyen kimenetelre nyitott, addig a Tanács mely a nemzeteket tömöríti - a jelenlegi jogszabályi keretek között kíván megmaradni, ${ }^{42}$ mások viszont - EP, civil szervezetek - szorosabb kooperációt szeretnének. ${ }^{43}$

A tagállamok közötti törésvonalak viszont már e konferenciasorozat alkalmával is a kezdetekkor kirajzolódtak. A korábbi egyeztetésekhez hasonlóan az egyik fajta megosztottság az országok méretéből fakad, és leglátványosabban a transznacionális pártlisták megítélésével kapcsolatban mutatkozott meg. A nagy nemzetek - Franciaország, Németország és Spanyolország - ezek létrehozását szorgalmazzák, a kisebb államok - Bulgária, Hollandia, Szlovákia, vagy éppen Finnország ugyanakkor nem támogatják az ötletet, tartva attól, hogy az a saját országuk alulreprezentáltságát vonná maga után az Európai Parlamentben. ${ }^{44} \mathrm{~A}$ másik, hagyományosnak számító ellentétet az integráció jövőjével kapcsolatos felfogás jelenti, mely a CoFoE-n elsősorban a Tanács döntéshozatala kapcsán volt megfigyelhető. Míg az együttműködés mélyítése mellett kiálló tagországok - közöttük Hollandia, Belgium és Németország - megszüntetnék az egyhangú döntéshozatal intézményét, különösképpen a kül-, illetve adópolitikával összefüggő kérdésekben, és helyette a minősített többséggel történő elfogadást alkalmaznák, addig az államok másik csoportja - például Magyarország,

\footnotetext{
${ }^{41}$ A tanulmány lezárásáig a négy európai polgári vitafórum első ülésszaka és két plenáris ülés zajlott le.

${ }^{42}$ Council of the European Union 2021.

${ }^{43}$ CoFoE 2021a.

44 Ålander et al. 2021. 3.
} 
Görögország, Írország, vagy éppen Dánia - a különböző politikai kultúrák tiszteletben tartását, a nemzetek egyenlőségének fontosságát hangsúlyozza és megőrizné a vétójogot a fentebb említett területeken. ${ }^{45}$

Az Európa jövőjéről szóló konferenciával egyidőben zajló külpolitikai események szintén hatást gyakoroltak az egyeztetésekre. Noha az elnökség a tárgyalandó témák körét rendkívül szélesen határozta meg, a CoFoE kezdetét megelőzően a legnagyobb várakozások az intézményi reformokkal - csúcsjelölti rendszer, transznacionális pártlisták bevezetése - kapcsolatban voltak. Az uniós rendezvénnyel egyidejüleg, de tőle függetlenül bekövetkező világpolitikai változások azonban felülírták az előzetes elgondolásokat. A 2020-as koronavírus-járvány következtében ezen ügyek mellett a gazdasági problémák kezelése, az Unió szociális dimenziójának erősítése, valamint az egészségügyi kooperáció, annak fejlesztése is nagyobb hangsúlyt kapott annál, mint amire a konferenciát megelőzően számítani lehetett.

\section{Hasonlóságok és különbözőségek az európai integráció jövőjével kapcsolatos döntéshozatali folyamatokban}

Ahogyan azt a történeti példák mutatják, az európai integráció hosszú távú jövőjéről való egyeztetésre nem a kormányközi konferenciák jelentik az egyetlen lehetséges színteret. A 2002-2003-as Európai Konventnek szintén az Európai Unió új irányvonalainak meghatározása volt a célja és a 2021-2022-es Európa jövőjéről szóló konferencia is hasonló okból kerül megrendezésre. Tanulmányomban e három fórum döntéshozatali folyamatait hasonlítottam össze, azt vizsgálva, hogy milyen tényezők és hogyan gyakorolnak hatást a tárgyalófelek magatartására, illetve, hogy ezek tekintetében, van-e annak jelentősége, hogy míg az IGC-k során a tagállamok egy - teljesen, vagy egyes részeiben - új szerződés megalkotására törekszenek, addig a konventtagok egy kormányközi konferencia számára dolgoztak ki tárgyalási alapot, a 2021-ben kezdődött konferencián pedig a résztvevők csupán a meglévő jogi keretek között keresnek új utakat.

Kutatásom eredményei alapján hét olyan főbb pont határozható meg, amelyek a viták során befolyással voltak - és vannak - a szereplők egyes témákban elfoglalt álláspontjára: az intézményi háttér, a tagországok integrációval kapcsolatos felfogása, a tagállamok mérete, a bel-, illetve

\footnotetext{
${ }^{45}$ CoFoE 2021b.
} 
külpolitikai események, a döntéshozatal módja, valamint a ratifikációs kötelezettség.

Valamennyi színtéren a végrehajtó hatalmak képviselői mellett jelen voltak más intézmények - például Európai Bizottság, Európai Parlament delegáltjai is, akik informális vagy formális csatornákon keresztül igyekeztek érdekeiket érvényre juttatni, saját jelentőségük növelése, megőrzése céljából. A kormányközi konferenciákon az EB-nek és az EPnek ugyan nincsen jogilag lehetősége arra, hogy a megbeszéléseket szándékaiknak megfelelően alakítsák, ám a napirend meghatározásában érdemi hatásuk lehet. Az IGC-kkel ellentétben viszont a Konventen és a CoFoE-n teljes jogú tagságuknak köszönhetően már az ő egyetértésük is kellett - és kell - a konszenzus kialakulásához. A szupranacionális résztvevők célkitűzései többnyire a közösségi dimenzió erősödését vonták volna maguk után, ahogyan az például látható volt az Európai Konvent alkalmával, mikor is az EP az összes szakpolitikai területre szerette volna kiterjeszteni társjogalkotó szerepét. Törekvéseik ugyanakkor nem mindig estek egybe a tagországok érdekeivel, mely esetekben a nemzetek akarata volt a döntő.

Az államok között húzódó két nagy törésvonal, a szuverenista és a föderalista felfogásból, valamint a méretből fakadó nézetkülönbségek hasonlóképpen felfedezhetőek voltak az együttműködés jövőjéről folytatott vitákban. Előbbi megosztottság legélesebben akkor rajzolódott ki, mikor a résztvevők az EU szupranacionális jellegének erősítéséről egyeztettek, úgy, mint például az uniós intézmények hatásköreinek bővítéséről, vagy éppen a döntéshozatali szabályok módosításáról. Annak jelentősége pedig, hogy egy politikus kis, vagy nagy tagországból érkezett, elsősorban az intézményi átalakításokkal kapcsolatban mutatkozott meg. A jobb gazdasági és demográfiai adatokkal bíró nemzetek a hatékonyabb múködésre, egységesebb fellépésre helyezték a hangsúlyt, ahogyan az történt például az Európai Tanács, illetve a Bizottság létszáma esetében is, a kisebb államok viszont ezzel szemben befolyásuk megőrzését tartották a legfontosabbnak.

A kormányközi konferenciákon tapasztaltakból kitűnt az is, hogy a rendezvényekkel párhuzamosan zajló bel- és külpolitikai események ugyancsak képesek érdemi befolyást gyakorolni a döntéshozatal folyamatok alakulására. A 2003-2004-es IGC-n a szavazási súlyok megváltoztatásával szembeni spanyol ellenállás a 2004-es kormányváltással szűnt csak meg, az 1991-es öbölháború következményeképpen pedig a tárgyalófelek nagyobb figyelmet fordítottak a külpolitikai együttműködésre a Maastrichti Szerződést megelőző 
kormányközi konferencián. A nemzetközi környezetben zajló változások úgy, mint a 2020-ban kitört koronavírus-járvány, vagy korunk modernizációs folyamatai - az Európa jövőjéről szóló konferencia keretében folyó vitákra is hatással voltak, hiszen ezeknek köszönhetően kaptak kiemelt hangsúlyt a digitális átalakulás, az egészségügy és az EU szociális dimenziójának kérdései a 2021-2022-es tanácskozáson. A rendezvénysorozat idejére eső német szövetségi parlamenti választás ugyancsak magában hordozza a változás lehetőségét, tekintettel arra, hogy a Merkel-kormánnyal szemben valamennyi német párt elkötelezett az Európai Parlament hatáskörének kibővítése mellett, a jogalkotási kezdeményezéshez való jog biztosítása formájában, így az intézményi reformok terén új álláspontra helyezkedhet majd a megalakuló végrehajtó hatalom.

A fent leírt tényezők valamennyi színtéren megfigyelhetőek voltak, vagy legalábbis megjelenhettek volna, nem függtek az egyeztetések kimenetelétől. Mellettük azonban két olyan feltételről is beszélhetünk - a hazai ratifikációs kényszer és az egyhangú döntéshozatal -, melyek fennállását, illetve hiányát a tárgyalások pontos végcélja határozta meg.

A kormányközi konferenciák végén az állam- és kormányfők közül mindenkinek egyet kell értenie az előttük fekvő szerződéstervezettel, annak aláírása kizárólag egyöntetű elfogadás esetén, vétó nélkül lehetséges. Hatályba lépéséhez pedig a nemzeti parlament, vagy a választópolgárok általi jóváhagyás szükséges, ennek szabályairól minden ország saját maga dönt. Az IGC-kkel szemben a Konventen és az Európa jövőjéről szóló konferencián a tagok konszenzussal döntöttek - és döntenek - a plenáris üléseken, amelyek nem jelentenek egyet az egyhangúsággal. Utóbbi rendezvénynek külön sajátossága, hogy a konszenzusnak csupán az uniós, illetve nemzeti politikusok között kell létrejönnie, amennyiben a civilek képviselői eltérő véleményen vannak, úgy azt az Igazgatóságnak külön kell majd jeleznie végső jelentésében az elnökség felé. ${ }^{46}$ Ezen túlmenően, tekintettel arra, hogy sem az Európai Konvent, sem a CoFoE nem szerződésmódosításra irányult, a feleknek nem kellett - és nem kell - ügyelniük a majdani sikeres ratifikációra. Mindezeknek az lett a következménye, hogy a kormányközi konferenciákon a politikusoknak gyakran csak különféle alkuknak köszönhetően sikerült megállapodniuk az egyes ügyekben, azokat pedig, amelyekben nem sikerült áthidalniuk a nézeteltéréseiket egy következő alkalomra halasztották - ahogyan azt tették például a 2000-es IGC-n is. Ezekkel az esetleges vétózás elkerülése mellett, az elkészített jogszabály

\footnotetext{
${ }^{46}$ Rules of Procedure 2021.
} 
belpolitikai támogatását is biztosítani akarták. A Konventen viszont, bár nem volt szükség minden európai vezető egyetértésére, néhányuk olyan témákban is engedményt tett, melyekben, más helyzetben másképpen cselekedtek volna. Ez magyarázható egyfelől azzal, hogy nem kötötték őket a hazai korlátok, másfelől pedig tisztában voltak azzal, hogy a változtatások hatályba lépéséhez később még egyszer kelleni fog a beleegyezésük. Hasonlóak a körülmények az Európa jövőjéről szóló konferencián is, így annak során szintén ambiciózusabb megállapodásokra nyílik lehetőség, mint amilyenekre egy kormányközi konferencián lenne mód.

\section{Felhasznált irodalom}

Ålander, Minna - von Ondarza, Nicolai - Russack, Sophia (eds.) (2021): Managed Expectations: EU Member States' Views on the Conference on the Future of Europe. European Policy Institutes Network Report. 24 June 2021. https://epin.org/wp-content/uploads/2021/06/ManagedExpectations-EU-Member-States\%E2\%80\%99-Views-on-the-Conferenceon-the-Future-of-Europe.pdf (2021.11.01.)

Beach, Derek (2012): The Constitutional Treaty: The Failed Formal Constitutionalisation. In: Laursen, Finn (ed.): Designing the European Union: From Paris to Lisbon. London: Palgrave Macmillan. 217-243.

\section{https://doi.org/10.1057/9780230367579 10}

Bickerton, Christopher J. - Hodson, Dermot - Puetter, Uwe (2015): The New Intergovernmentalism: States and Supranational Actors in the PostMaastricht Era. Oxford: Oxford University.

\section{https://doi.org/10.1093/acprof:oso/9780198703617.001.0001}

Budden, Philip (2002): Observations on the Single European Act and 'relaunch of Europe': a less 'intergovernmental' reading of the 1985 Intergovernmental Conference. Journal of European Public Policy, Vol. 9 No. 1, 76-97.

\section{https://doi.org/10.1080/13501760110104181}

Christiansen, Thomas (2002): The role of supranational actors in EU treaty reform. Journal of European Public Policy, Vol. 9, No. 1, 33-53.

\section{https://doi.org/10.1080/13501760110104163}


CoFoE (2021a): Conference on the Future of Europe - Plenary session. 2021.10.23. https://audiovisual.ec.europa.eu/en/video/I-212931 (2021.11.01.)

CoFoE (2021b): Inaugural plenary of the Conference on the Future of Europe. 2021.06.19. https://multimedia.europarl.europa.eu/en/inauguralplenary-of-conference-on-future-of-europe 20210619-0900-SPECIALOTHER vd (2021.11.01.)

Council of the European Union (2021): Conference on the Future of Europe - revised Council position. 5911/21. AG 12. INST 46. https://data.consilium.europa.eu/doc/document/ST-5911-2021INIT/en/pdf (2021.11.01.)

De Schoutheete, Philippe - Wallace, Helen S. (2002): The European Council. Bruxelles: Notre Europe.

Dehousse, Renaud - Deloche-Gaudez, Florence (2005): The Making of a Transnational Constitution: An Institutionalist Perspective on the European Convention. Les Cahiers européens de Sciences Po, $n^{\circ}$ 02, Paris: Centre d'études européennes at Sciences Po.

Devuyst, Youri (1998): Treaty reform in the European Union: the Amsterdam process. Journal of European Public Policy, Vol. 5, No. 4, 615631.

\section{https://doi.org/10.1080/13501769880000051}

European Council (2001): Presidency Conclusions: European Council Meeting in Laeken. 14 and 15 December 2001. SN 300/1/01 Rev 1, Brussels, 14 December 2001.

Falkner, Gerda (2002): EU treaty reform as a three-level process. Journal of European Public Policy, Vol. 9, No. 1, 1-11.

\section{https://doi.org/10.1080/13501760110104145}

Giscard d'Estaing, Valéry (2002): Introductory speech by President V. Giscard d'Estaing to the Convention on the Future of Europe. https://web.archive.org/web/20050527185629/http://europeanconvention.eu.int/docs/speeches/1.pdf (2021.11.01.)

Hix, Simon (1999): The Political System of the European Union. Basingstoke: Palgrave Macmillan.

https://doi.org/10.1007/978-1-349-27531-1

Hix, Simon (2002): Constitutional Agenda-Setting through Discretion in Rule Interpretation: Why the European Parliament Won at Amsterdam. British Journal of Political Science, Vol. 32, No. 2, 259-280. 
https://doi.org/10.1017/S0007123402000108

Joint Declaration on the Conference on the Future of Europe. 2021. https://ec.europa.eu/info/sites/default/files/en joint declaration on the conference on the future of europe.pdf (2021.11.01.)

König, Thomas - Slapin, Jonathan B. (2006): From Unanimity to Consensus: An Analysis of the Negotiations at the EU's Constitutional Convention. World Politics, Vol. 58 No. 3, 413-445.

https://doi.org/10.1353/wp.2007.0002

Laursen, Finn (2012): Introduction: On the Study of EU Treaties and Treaty Reforms. In: Laursen, Finn (ed). Designing the European Union: From Paris to Lisbon. London: Palgrave Macmillan. 1-15.

https://doi.org/10.1057/9780230367579 1

Macron, Emmanuel (2019): Pour une Renaissance européenne. https://www.elysee.fr/emmanuel-macron/2019/03/04/pour-unerenaissance-europeenne (2021.11.01.)

Magnette, Paul - Nicolaïdis, Kalypso (2004): The European Convention: Bargaining in the Shadow of Rhetoric. West European Politics, Vol. 27, 0. 3, 381-404. https://doi.org/10.1080/0140238042000228068

Magnette, Paul - Nicolaïdis, Kalypso (2005): Coping with the Lilliput Syndrome: Large vs. Small Member States in the European Convention. European Public Law, Vol. 11, No. 1, 85-104.

Moravcsik, Andrew - Nicolaïdis, Kalypso (1998): Keynote Article: Federal Ideals and Constitutional Realities in the Treaty of Amsterdam. Journal of Common Market Studies: Annual Review. 13-38.

Moravcsik, Andrew - Nicolaïdis, Kalypso (1999): Explaining the Treaty of Amsterdam: Interests, Influence, Institutions. Journal of Common Market Studies, Vol. 37, No. 1, 59-85.

https://doi.org/10.1111/1468-5965.00150

Moravcsik, Andrew (1991): Negotiating the Single European Act: national interests and conventional statecraft in the European Community. International Organization, Vol. 45, No. 1, 19-56.

https://doi.org/10.1017/S0020818300001387

Peterson, John - Bomberg, Elizabeth (1999): Decision-making in the European Union. Basingstoke: Macmillan.

https://doi.org/10.1007/978-1-349-27507-6 
Putnam, Robert D. (1988): Diplomacy and Domestic Politics: The Logic of Two-Level Games. International Organization, Vol. 42, No. 3, 427-460.

https://doi.org/10.1017/S0020818300027697

Rules of Procedure of the Conference on the Future of Europe. 2021. https://futureu.europa.eu/uploads/decidim/attachment/file/9340/sn02700 .en21.pdf (2021.11.01.)

Slapin, Jonathan B. (2011): Veto Power: institutional design in the European Union. Michigan: University of Michigan.

Stubb, Alexander (2002): Negotiating Flexibility in the European Union: Amsterdam, Nice and Beyond. Basingstoke: Palgrave Macmillan.

https://doi.org/10.1057/9781403907615

Sverdrup, Ulf (2002): An institutional perspective on treaty reform: contextualizing the Amsterdam and Nice Treaties. Journal of European Public Policy, Vol. 9, No. 1, 120-140.

https://doi.org/10.1080/13501760110104208

***

\section{Determinants of the debates on the future of European integration: a comparative analysis of the Intergovernmental Conferences, the European Convention and the Conference on the Future of Europe}

\section{Summary}

The ongoing Conference on the Future of Europe is the third type of events - after the Intergovernmental Conferences and the European Convention - where the heads of state or government of the Member States seek to shape the long-term future of the European community. Although the decisions have impact on our lives, we know very little about the factors that influence politicians' viewpoints on particular issues. By comparing these three types of events, this paper aims to reveal what are the most significant things that affect the attitudes of European leaders when they discuss the direction in which European integration should develop in the future. 